\title{
SPRING 1983
}

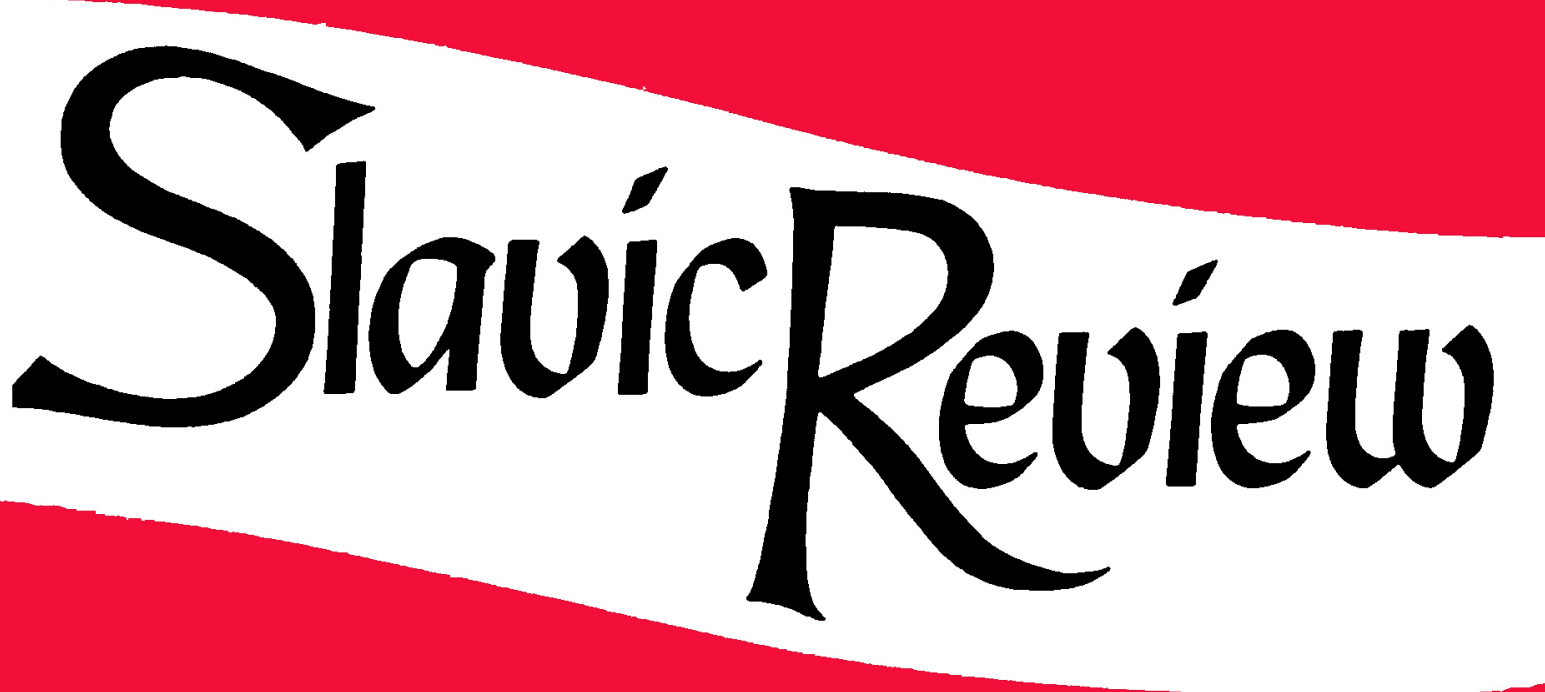

\section{AMERICAN QUARTERLY OF SOVIET AND EAST EUROPEAN STUDIES}

Jean Ispa : Soviet and American Childbearing Experiences and Attitudes: $A$ Comparison

Piotr Gorecki : Viator to Ascriptitius: Rural Economy, Lordship, and the Origins of Serfdom in Medieval Poland

William G. Wagner : The Civil Cassation Department of the Senate as an Instrument of Progressive Reform in Post-Emancipation Russia:

The Case of Property and Inheritance Law

\section{DISCUSSION}

J. Arch Getty : Party and Purge in Smolensk: 1933-1937 Comments by Robert C. Tucker and Niels Erik Rosenfeldt 


\section{EDITOR}

\section{DaVID L. RANSEL}

\begin{tabular}{|c|c|}
\hline ASSOCIATE EDITOR & GITTA BRIDGES \\
\hline ASSISTANT EDITOR & Maria P. Dunatov \\
\hline STAFF ASSISTAN] & Melisa A \\
\hline
\end{tabular}

HONORARY EDITORS: Frederick Barghoorn • John S. Curtiss • John N. Hazard • Gleb Struve $\cdot$ Marc M. Szeftel $\cdot$ René Wellek

EDITORIAL BOARD: John T. Alexander, University of Kansas • Bohdan R. Bociurkiw, Carleton University $\cdot$ George W. Breslauer, University of California $\cdot$ Malcolm Hamrick Brown, Indiana University • Patricia Carden, Cornell University • Elizabeth Clayton, University of Missouri, St. Louis • Vera S. Dunham, Queens, CUNY • Paul R. Gregory, University of Houston - Keith Hitchins, University of Illinois at Urbana-Champaign • Michael J. Holquist, Indiana University - Ann M. Kleimola, University of Nebraska • Bernice Madison, San Francisco State College $•$ Robert A. Maguire, Columbia University • Walter M. Pintner, Cornell University • Richard W. Pope, York University • James P. Scanlan, Ohio State University • H. Gordon Skilling, University of Toronto • Gale Stokes, Rice University • Alexander Vucinich, University of Pennsylvania

CONSULTANTS ON SOVIET AND EAST EUROPEAN BOOKS: George Barany, University of Denver • John D. Bell, University of Maryland Baltimore County $\cdot$ Imre Boba, University of Washington - Wesley A. Fisher, Columbia University • Keith Hitchins, University of Illinois at Urbana-Champaign - Charles Jelavich, Indiana University • John E. Malmstad, Columbia University - Daniel Orlovsky, Southern Methodist University • Joseph F. Zacek, SUNY, Albany • Richard King, coordinator

The editors assume no responsibility for statements of fact or opinion made by contributors.

The Slavic Review (ISSN 0037-6779) (formerly The American Slavic and East European Review) is published quarterly by the American Association for the Advancement of Slavic Studies, Inc., and is sent to all Association members. Members also receive the AAASS Newsletter. Membership applications from individuals professionally engaged in the field are accepted by the Executive Director, Dorothy Atkinson, Department of History, Stanford University, Stanford, CA 94305 . Membership dues: salary $\$ 10,000$ to $\$ 19,999-\$ 25.00$; $\$ 20,000$ to $\$ 29,999-\$ 30.00 ; \$ 30,000$ to $\$ 39,000-\$ 35.00$; over $\$ 40,000-\$ 40.00$. Joint members with one subscription to the Slavic Review, add $\$ 10.00$ to dues of higher paid member. Dues for students at member institutions are $\$ 12.50$; other students, emeriti, or those with salaries under $\$ 10,000$ pay $\$ 15.00$. Subscriptions without membership are $\$ 45.00$. Single current issues are $\$ 10.00$; back issues are $\$ 10.00$ each. Correspondence regarding membership, subscriptions, changes of address, or items for the Newsletter should be sent to the AAASS headquarters in Stanford.

Articles, books for review, and correspondence concerning advertising and editorial matters should be sent to Slavic Review, University of Illinois at Urbana-Champaign, 911 West High Street, Room 200, Urbana, Illinois 61801. Technical requirements for manuscript submissions are given on the inside back cover.

Published by the American Association for the Advancement of Slavic Studies, Inc. Composition by Brevis Press, Cheshire, Connecticut. Printed by Heffernan Press, Inc., Worcester, Massachusetts. Second-class postage paid at Palo Alto, CA and additional mailing office. POSTMASTER: Send address changes to Slavic Review, c/o AAASS, Department of History, Stanford University, Stanford, CA 94305.

Copyright $\odot 1983$ by the American Association for the Advancement of Slavic Studies, Inc. 


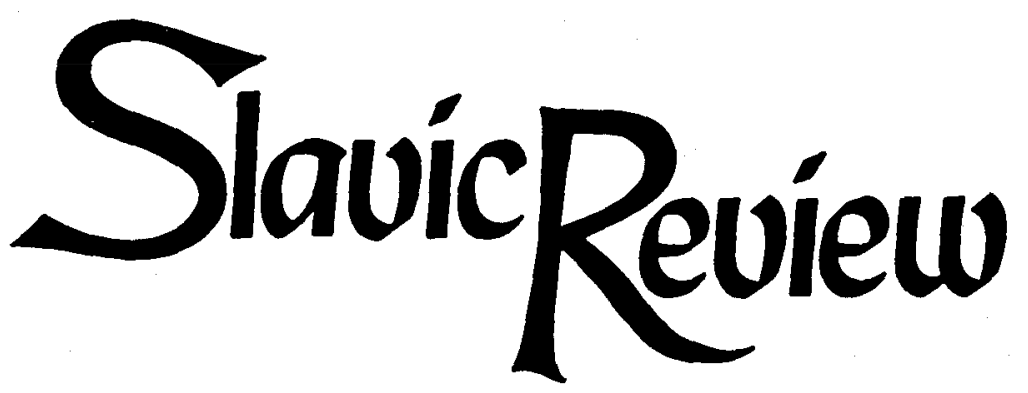

AMERICAN QUARTERLY OF SOVIET AND

EAST EUROPEAN STUDIES

\author{
EDITOR \\ DAVID L. RANSEL \\ University of Illinois at Urbana-Champaign
}

Volume $42 \cdot 1983$

Copyright (C) 1983 by the American Association

for the Advancement of Slavic Studies, Inc. 


\section{CONTENTS OF VOLUME 42}

\section{Number 1, Spring 1983}

\section{ARTICLES}

Jean Ispa: Soviet and American Childbearing Experiences and Attitudes: A Comparison

Piotr Gorecki: Viator to Ascriptitius: Rural Economy, Lordship, and the Origins of Serfdom in Medieval Poland

William G. Wagner: The Civil Cassation Department of the Senate as an Instrument of Progressive Reform in Post-Emancipation Russia: The Case of Property and Inheritance Law

\section{DISCUSSION}

J. Arch Getty: Party and Purge in Smolensk: 1933-1937 60

Robert C. Tucker: Problems of Interpretation 80

Niels Erik Rosenfeldt: Problems of Evidence $\quad 85$

J. Arch Getty: Reply

REVIEW ESSAY

Ivo Banac: New Studies on the Social History of Croatia 97

$\begin{array}{ll}\text { REVIEWS } & 101\end{array}$

$\begin{array}{ll}\text { LETTERS } & 162\end{array}$

$\begin{array}{ll}\text { NEWS OF THE PROFESSION } & 164\end{array}$

$\begin{array}{lr}\text { BOOKS RECEIVED } & 168\end{array}$

$\begin{array}{ll}\text { SYMPOSIA } & 174\end{array}$

\section{Number 2, Summer 1983}

\section{ARTICLES}

Stephanie Sandler: The Poetics of Authority in Pushkin's

"André Chénier"

John M. Kramer: The Environmental Crisis in Eastern Europe: The Price for Progress

Evan E. Anderson: Central Planning and Production Instabilities in Eastern Europe

Anne D. Rassweiler: Soviet Labor Policy in the First Five-Year Plan: The Dneprostroi Experience

NOTES AND COMMENT

Alexander Yanov: Flight from Theory 
Kevin Moss: A Typology of Embedded Texts in The Brothers Karamazov

Donald Ostrowski: Did a Church Council Meet in 1581? A Question of Method

REVIEW ESSAYS

John E. Malmstad: Belyi: A Centenary Unobserved

Harold B. Segel: New Books on Russian Drama

REVIEWS

NEWS OF THE PROFESSION

BOOKS RECEIVED 354

$\begin{array}{ll}\text { SYMPOSIA } & 359\end{array}$

\section{ARTICLES}

\section{Number 3, Fall 1983}

Theodore H. Von Laue: Stalin in Focus

Robert Whittaker: "My Literary and Moral Wanderings":

Apollon Grigor'ev and the Changing Cultural Topography of Moscow

Ann E. Healy: Tsarist Anti-Semitism and Russian-American Relations

Tönu Parming: The Electoral Achievements of the Communist Party in Estonia, 1920-1940

Ivo Banac: The Confessional "Rule" and the Dubrovnik Exception: The Origins of the "Serb-Catholic" Circle in Nineteenth-Century Dalmatia

REVIEWS

REFERENCE BOOKS OF 1981-82: A SELECTION 541

$\begin{array}{lr}\text { LETTERS } & 550\end{array}$

NEWS OF THE PROFESSION 553

BOOKS RECEIVED $\quad 554$

$\begin{array}{lr}\text { SYMPOSIA } & 559\end{array}$

\section{Number 4, Winter 1983}

\section{ARTICLES}

David Joravsky: The Stalinist Mentality and the Higher Learning

Charles Jelavich: Serbian Textbooks: Toward Greater Serbia or Yugoslavia? 
Donna Orwin: Prince Andrei: The Education of a Rational Man

Marjorie Mandelstam Balzer: Ethnicity Without Power:

The Siberian Khanty in Soviet Society

NOTES AND COMMENT

Horace W. Dewey and Natalie Challis: Disparate Images of Mikhail Klopskii

REVIEW ESSAYS

George Barany: A Hero Remembered

657

Vojtech Mastny: Post-Revisionist Cold War

Richard D. Anderson, Jr.: Questions of Evidence and Interpretation in Two Studies of Soviet Decisions in the Berlin Crises

$\begin{array}{ll}\text { REVIEWS } & 679\end{array}$

$\begin{array}{ll}\text { LETTERS } & 741\end{array}$

$\begin{array}{ll}\text { NEWS OF THE PROFESSION } & 742\end{array}$

DOCTORAL DISSERTATIONS, 1982-1983

(Compiled by Jesse J. Dossick)

$\begin{array}{ll}\text { BOOKS RECEIVED } & 757\end{array}$

INDEX TO VOLUME $42(1983) \quad 762$ 